\title{
Effect of Environmental and Social Cost on Performance of Manufacturing Companies in Nigeria
}

\author{
Ngozi. G Theduru Ph.D (FCA) \\ Faculty of Business Administration \\ Department Of Accountancy \\ Imo State University, Owerri, Nigeria \\ E-mail: ngoziihedura@imsu.edu.ng \\ Ike Romanus Chukwuma \\ School Of Postgraduate Studies \\ Faculty of Business Administration \\ Department Of Accountancy \\ Imo State University, Owerri, Nigeria
}

\begin{abstract}
This study examines the effect of environmental and social costs on performance of manufacturing companies in Nigeria. The objectives of this study are to examine the relationship between environmental and social costs and performance of manufacturing companies in Nigeria. The data for the study were collected from annual reports and accounts of fourteen (I4) randomly selected manufacturing companies in Nigeria. The data were analyzed using multiple regression models. The key findings of the study shows that there is significant negative relationship between Environmental and social costs and Return on Capital Employed (ROCE) and Earnings per share (EPS) and a significant positive relationship between environmental and social costs and Net Profit Margin (NPM) and Dividend per Share (DPS). Based on this it was recommended that government should give tax credit to organizations that comply with its environmental laws in order to reduce their environmental costs and that environmental reporting should be made compulsory in Nigeria so as to improve the performance of organizations and the nation as a whole.
\end{abstract}

Keywords: Environmental Accounting, Social costs, Performance, Return on Capital Employed, Earnings per Share, Net Profit Margin and Dividend per Share.

\section{Introduction}

Accounting for environment helps in accurate assessment of cost and benefits of environmental preservation measures of companies (Schaltegger, 2000). It provides a common framework for organizations to identify and account for past, present and future environmental costs to support managerial decision making, control, planning and public disclosure (KPMG and UNEP, 2006). Environmental accounting is helpful in presenting in a transparent manner, the utilization of natural resources of the country, the cost incurred to use them and the income earned therefrom. It helps in measuring the contribution made by various companies in fulfilling their social responsibilities (Maheshwari, 20I3).

The emergence of Corporate Environmental Reporting (CER) in Nigeria has been an important development for better environmental management and overall corporate governance. Global awareness of stakeholders on corporate environmental performance has already made traditional reporting redundant. Companies run into the risk of loss of faith of their stakeholders, if in future, environmental performance information is not included in their main stream reporting (Swift, 200I). Evaluating the harmful effects on environmental pollution, great importance is attached not only to the profitability of companies but also to its environmental and social impact. The concept of Corporate Social Responsibility (CSR) and it's emphasize on responsibility towards the company's stakeholders viz employees, local community, general public and the future generation.

With the present laws on environmental management in place, manufacturing companies are subjected to comply with the environmental laws. This study seeks to investigate the extent $\mathrm{n}$ which costs incurred by companies as a result of being environmental friendly will affect the companies' financial performance. 


\section{I.I Statement of the Problem}

The rising concern about environmental degradation, resources depletion, and wasting of natural resources in the Niger Delta area is a source of concern. Many manufacturing companies in Nigeria are usually faced with youth restiveness as a result of unemployment and non - availability of social infrastructures. This has led to series of vandalization of Oil pipelines and other valuable properties of the company which in turn affect the environment adversary. These problems could be solved if the manufacturing companies in Nigeria manage their social and environmental costs efficiently and effectively. Based on these problems, the researcher deemed it necessary to examine how the manufacturing companies can manage their environmental and social costs and at the same time earn profit.

\section{I.3 Objectives of the Study}

The main objective of this study is to evaluate the effect of environmental and social costs on the performance of manufacturing companies in Nigeria. Other specific objectives include to:

- Investigate the significant effect of environmental and social costs on Return on Capital employed (ROCE).

- Examine the significant effect of environmental and social costs on Net Profit Margin (NPM).

- Evaluate the effect of environmental and social costs on Dividend per Share (DPS).

- Examine the significant effect of environmental and social costs on Earnings per Share (EPS).

\section{I.4 Research Questions}

- To what extent do environmental and social costs affect Return on Capital Employed (ROCE)?

- How significant is the effect of environmental and social costs on Net Profit Margin (NPM)?

- What is the effect of environmental and social costs on Dividend per Share (DPS)?

- What is the effect of environmental and social costs on Earnings per Share (EPS)?

\section{I.5 Research Hypotheses}

The following research hypotheses were formulated and expressed in their null form(s).

- HOı: Environmental and social costs have no significant effect on Return on Capital employed of manufacturing companies.

- $\mathrm{HO}_{2}$ : Environmental and social costs have no significant effect on the Net Profit Margin of manufacturing companies.

- $\mathrm{HO}_{3}$ : Environmental and social costs have no significant effect on the Dividend per Share of manufacturing companies.

- $\mathrm{HO}_{4}$ : Environmental and social costs have no significant effect on the Earnings per Share of manufacturing companies.

\section{Review of Related Literature \\ 2.I Conceptual Framework}

\section{I.I Concept of Social Accounting}

Social accounting is concerned with the measurement and disclosure of costs and benefits to the society as a result of operating activities of a business enterprise. Thus, social accounting measures social costs and social benefits as a result of business activities for communication to various groups both within and outside the business (Maheshwari, 2013). Wason (2006) defined Social accounting as that part of accounting concerned with the process of identification, measurement and communicating the contribution made by the business enterprise to the society in which the business enterprise is born and thereafter grow. Iheduru (2018) sees social accounting as the "process of communicating the social and environmental effects of organizations' economic actions to particular interest groups within society and to society at large.

According to Crowther (2000) social accounting is an "approach to reporting a firm's activities which stresses the need for the identification of socially and relevant behavior, the determination of those to whom the company is accountable for its social performance and the development of appropriate measures ad reporting techniques. Environmental accounting is sometimes referred to as green accounting, resource accounting, integrated economic and environmental accounting refers to modification of the system of National accounts to incorporate the use or depletion of natural resources. It is the practice of accounting for all contributing factors that result in an impact on the environment (Akpan, 2013). It involves management of environmental costs effectively presenting and disclosing environmental information in a suitable form (Maheshwari, 2013) et al. Labaran (20II) postulates that environmental accounting often referred to green accounting incorporates environmental assets and their source and sink functions into National and Corporate accounts.

Maheshwari (2013) sees social costs as any cost or sacrifice to the society or any of its elements whether economic or non-economic, internal or external. He further, emphasized that social costs can be a sacrifice whether economic or noneconomic made by society and is not paid for such as damages to air, soil and water, due to disposal of waste by a business entity and if entity is making any payment for reduction of air, soil and water pollution, can be shown as social benefits. 


\subsubsection{Exploring the Concept of Environmental Costs}

Environmental costs are costs incurred by companies in order to prevent environmental problems and minimize damages to the environment. They are those costs incurred in compliance with, or prevention of breach environmental laws, regulations and company policies. However, the true environmental costs to a firm can be far broader, including costs of resources both those directly related to production and those involved in general business operations, waste treatment and disposal costs, the cost of poor environmental reputation and the costs of paying an environmental risk premium.

The U.S Environmental Protection Agency (I996) defines environmental costs as those costs that have direct financial impact on company (internal costs), and costs to individuals, society and the environment (external costs). Any activity conducted by enterprises in their environment leads to the emergence of environmental costs. Some of the environmental costs arise as a result of actions taken to protect the environment and occur as a result of the use of environmental resources. Another part of these costs arises due to environmental pollution caused by these companies. Environmental costs can be divided into three different groups: reduction costs, operating costs and damage costs (Otlu \& Kaya, 2010).

\subsubsection{Categories of Environmental Costs}

Environmental costs can be categorized into costs that directly impact on a company's bottom-line, which are referred to as private costs and costs to individuals, society and the environment for which a company is not accountable, which are called societal cost. Private costs can further be classified into, conventional costs, potentially hidden costs, contingent costs and image and relationship costs. This classification creates both a decision-oriented information base for the environmental management system and for the planning, control and supervision of material and energy flows (Lethmate \& Doost, 2000, Labarn, 20I I, Iheduru, 2018).

- Conventional Costs: The costs of using raw materials, utilities, capital goods and supplies are usually addressed in cost accounting and capital budgeting. However, the environmental portion of these costs into business decisions, whether are not they are seen as environmental costs.

- Potentially Hidden Costs: These are environmental costs that may be potentially hidden from managers because of their infrequent nature and / or because of their collection in company overhead accounts (EPA 742 -R-95-003, 1995). Different types of environmental costs that may be potentially hidden from managers are: upfront environmental costs, regulatory and voluntary environmental costs and back -end environmental costs.

- Contingent Costs: These are costs that may or may not be incurred at some point in the future. Examples include the costs of remedying and compensating for future accidental releases of contaminant into the environment (example, oil spills), fines and penalties for future regulatory infractions. Because these costs may not currently need to be recognized for other purposes, they may not receive adequate attention in internal management accounting systems and forwardlooking decisions.

- Image and Relationship Costs: These costs are incurred to affect subjective (though measurable) perceptions of management, customers, employees, communities and regulators. These costs have also been termed "corporate image" and "relationship" costs. This category can include the costs of annual environmental reports and community relations activities, costs incurred voluntarily for environmental activities (example, tree planting), and costs incurred for recognition programs. These costs themselves are not intangible, but the direct benefits that result from relationship or corporate image expenses often are.

- Societal Costs or External Costs: These are the costs a business impacts on the environment and society for which business is not legally accountable. They include environmental degradation and adverse impacts on human beings, their property and their welfare which cannot be compensated through the legal system.

At present, valuing societal costs is both difficult and controversial; nevertheless, it is essential for any environmentally friendly organization to determine external impacts and to the extent for any possible, value societal costs in order to integrate them into its planning and decision-making.

\subsection{Theoretical Framework}

This theoretical Framework of the study is anchored on legitimacy theory and shareholders theory.

\subsection{Legitimacy Theory}

Legitimacy is a generated perception or assumption that the actions of an entity are desirable, proper, or appropriate within some socially constructed system of norms, values and definitions (Suchman, 1995). This theory states that organizations seek to operate within what is considered acceptable in the society. What is considered as acceptable behavior changes overtime and the firm must be prepared for variations in the environment taking ethical aspects into account (Islam \& Deegan, 2007). Legitimacy may also be seen as a generalized perception or assumption that the action of an entity is desirable, proper or appropriate within some society constructed system of norms, values, beliefs and definitions (Gotherstrom, 2012). 
According to Tilling (2004), legitimacy theory offers a powerful mechanism for under standing voluntary social and environmental disclosure made by corporations, and that this understanding would provide a vehicle for engaging in critical public debate.

\subsubsection{Stakeholders Theory}

The basic proposition of the stakeholders theory is that the firm's success is dependent upon the successful management of all the relationships that a firm has with its stakeholders - a term originally introduced by Stanford research institute (SRI) to refer to those groups without whose support the organization would cease to exist, Freeman (I983). Freeman's stakeholders' theory asserts that, managers must satisfy a variety of constituents (example, employees, customers, suppliers, local community and so on) who can influence the firm's outcomes. According to this view, it is not sufficient for managers to focus exclusively on the needs of stakeholders, or the owners of the business. This implies that it can beneficial for the firm to engage in certain environmental activities that non-financial stakeholders perceive important, because without this, these groups might withdraw their support from the business.

In developing the stakeholder theory, Freeman (1983) incorporates the stakeholders' concept into categories: A business planning and policy model, and A corporate social responsibility model of stakeholder management.

In the first model, the stakeholder analysis focuses on developing and evaluating the approval of corporate strategy decisions by groups whose support is required for the firm's continued existence. The stakeholders identified in the model include the owners, customers, public groups and suppliers. Although these groups are not adversarial in nature, their possibly conflicting behavior is considered a constant on the strategy developed by management to best match their firm's resources with the environment (Degan \& Gordon, 1966). In the second model, the corporate planning and analysis extends to include external influences which may be adversarial to the firm. These adversarial groups may include the regulatory environmentalist and /or special interest groups concerned with social issues (Guthrie \& parker, 1990).

The second, model enables managers and accountants to consider a strategic plan that is adaptable to change in the social demands of non-traditional stakeholders groups. The stakeholders' theory proposed an increased level of environmental awareness which creates the need for companies to extend their corporate planning to include the non-traditional stakeholders like the regulatory adversarial groups in order to adapt to changing social demands (Trotman, 1999). The main concern of the stakeholders' theory in environmental accounting is to address the environmental cost elements and valuation and its inclusion in the financial statements.

\subsection{Empirical Review}

Bewley \& Li (2000) appealed to voluntary disclosure theory to examine the environmental disclosures of Canadian manufacturing firms. They used the Wiseman index to measure the I993 annual report disclosures of I88 firms and industry membership to proxy for pollution propensity. They found that firms with a higher pollution propensity and greater media coverage of their environmental performance are more likely to disclose general environmental information, a result also consistent with the socio political theories. Similarly, Hughes et al. (200I) examined environmental disclosures made by U.S. manufacturing firms in 1992 and 1993 using a modified Wiseman index to measure disclosures in the president's letter, MD \& A performance. They found that firms rated as poor by the CEP generally make the most disclosures.

Al-Tuwaijri et al. (2004) employed simultaneous equations approach to investigate the relations among environmental disclosure, environmental performance and economic performance. They used proxy for environmental performance using the percentage of total waste generated recycled as identified using the TRI database and measure environmental disclosure using a content analysis in four categories, potential responsible parties' designation, toxic waste, oil and chemical spills, and environmental fines and penalties, disclosures which are largely non-discretionary. Based on these proxies, Al-Tuwaijri et al. (2004) documented a positive association between environmental performance and environmental disclosure.

Salama (2005) used regression analysis to measure the impact of environmental performance on financial performance. The findings showed that a positive relationship existed between environmental performance and firm financial performance. Montabon, Sroufe, \& Narasimhan, (2007) in their paper examined the relationship between environmental management practices and firm performance. They established that a significant and positive relationship exists between environmental management practices and measures of firm performance Enahoro, (2009) used T-test statistics, Pearson product moment correlation and regression analysis and observed that environmental accounting disclosure does not take the same pattern among quoted firms in Nigeria.

Bassey, Sunday \& Okon (2013) on the other hand used Pearson's product moment correlation analysis of oil and gas companies in the Niger Delta region of Nigeria. They observed that environmental cost has satisfied relationship with firm's profitability. Adediran \& Alade (2013) used multiple regression analysis of I4 randomly selected companies quoted on the Nigerian Stock Exchange 20I0. Their findings show that environmental accounting has a positive relationship with net profit margin, dividend per share and a negative relationship with return on capital employed and earnings per share. 


\section{Research Methodology}

The research applied content analysis in examine the level of environmental and social costs disclosure of manufactory companies in Nigeria. The research designed used in this study is ex-post facto research deals with the determination, evaluation and explanation of past events essentially for the purpose of gaining a better and more reliable prediction of the future (Amahalu et al, 2015).

The population consists of fourteen (I4) randomly selected manufacturing companies for food and beverages sector, cement, etc quoted in the Nigeria stock Exchange for the year 20I6. The sample size of I4 companies selected randomly because these companies disclosure environmental costs in their annual report and accounts. The study makes use of secondary data, information from the Annual reports and accounts of manufactory companies quoted in the Nigerian Stock Exchange. The statistical tool for the Hypothesis was the ordinary least square regression method and E-view (3.I) version.

\section{Data Analysis}

\section{I Model Specification}

In order to analyze a relationship between different variable, the data were subjected to multiple regression analysis through the use of economic model. The model is specified below:

$\mathrm{ESC}=\mathrm{f}(\mathrm{ROCE}, \mathrm{NPM}, \mathrm{DPS}$ and EPS $)$

Where: ESC, ROCE, NPM, DPS and EPS represent Environmental and Social Cost of Companies; Return on Capital. The econometric form of the model is as follows:

$$
\mathrm{ESC}=\mathrm{a}_{\circ}+\mathrm{a}_{1} \mathrm{ROCE}+\mathrm{a}_{2} \mathrm{NPM}+\mathrm{a}_{3} \mathrm{DPS}+\mathrm{a}_{4} \mathrm{EPS}+\mathrm{u}_{\mathrm{t}}
$$

Where: a, a1, a2, аз a41 and ut represent intercept, Return on Capital Employed, Net Profit Margin, of Dividend per share, Earning per share and Error terms respectively. The apriori expectation is that Environmental Accounting has a positive relationship with the Return on Capital Employed (ROCE), Net Profit Margin (NPM) Dividend per share (DPS) and Earnings Per share (EPS) in the period under study. Amount spent by each company as their environmental cost was used as proxy for environmental accounting while Return on Capital Employed (ROCE), Net Profit Margin (NPM), Dividend Per Share (DPS) and Earnings Per Share (EPS) were used for firm performance.

The results for different measures of environmental accounting and performance of the firms including Return on Capital Employed, Net Profit Margin, Dividend Per Share and Earning Per Share are presented in the following section. First, the descriptive analysis is presented followed by multiple regression analysis to see the association between Net Operating Profitability and all independent variables.

\begin{tabular}{lrrrr}
\multicolumn{5}{c}{ Result of Regression Analysis } \\
\hline Variable & Coefficient & Std Error & T-Statistic & Prob \\
\hline ESC & 8939618 & 7253516 & -1248435 & 0.3562 \\
\hline ROCE & -29863504 & 13093548 & -3.579789 & 0.0250 \\
\hline NPM & 85688928 & 45425547 & 2.633716 & 0.410 \\
\hline DPS & 73438732 & I4624I2 & 4.802550 & $0.002 \mathrm{I}$ \\
\hline EPS & -806577.6 & 387849.9 & -1.964308 & 0.0872 \\
\hline R-Squared & 0.859172 & Mean dependent Var & 16958142 \\
\hline Adjusted R-squared & 0.777678 & S.D dependent var & 15885459 \\
\hline S.E of regression & 8245645 & Akaike info criterion & 35.83694 \\
\hline Sum squared & $5.98 \mathrm{E}+\mathrm{I} 2$ & Schewarz criterion & 37.17405 \\
\hline Log likelihood & -249.4506 & F-statistic & $\mathrm{I}$ \\
\hline Durbin-Watson stat & 2.149650 & Prob (F-statistic) & 0.001372 \\
\hline
\end{tabular}

Source: E-View (3.I) output

From the result above, the regression equation is rewritten as:

$\mathrm{ESC}=89396 \mathrm{I} 8-2986350 \mathrm{ROCE}+85688928 \mathrm{NPM}+73438732 \mathrm{DPS}-806577.6 \mathrm{EPS}$

T-Ratio $=(-1248435)(-3.579789)(2.633716)(4.802550)(-1.964308)$

R-Squared $=0.859172$ Adjusted R-squared $=0.777678$. S.E of Registration $=8245645$

F-Stat $=12.95815$ DW Statistic $=2.149650$ 
From the result presented above, all the variables except Return on Capital Employed (ROCE) and Earning Per Share (EPS) are in line with the prior expectation. It can also be seen that Environmental and Social cost has a positive relationship with Net Profit Margin (NPM) and Dividend per Share (DPS) and a negative relationship with return on capital Employed (ROCE) and Earnings per Share (EPS) in the period under study. Using the co-efficient of variation from the model presented above, it will be observed that autonomous Environmental and Social cost which is represented by Environmental Cost (ESC) is a negative 8839618 when all other variables are held constant.

Consequently, a unit charge in Environmental and Social Cost (ESC) will lead to negative change of about 29863504 units in ROCE less the autonomous component provided all other variables arc held constant. Also, a unit change in ESC provided all other variables are held constant will have a positive change of about 85688928 units in NPM less the autonomous component.

Furthermore, a unit change in ESC will lead to a positive change of about 73438732 units in DPS less the autonomous component. And a unit change in ESC will lead to a negative change of 806577.6 units in EPS.

Using the T-Ratio to test for their statistical significance, it is evident that only NPM and DPS variables are statistically significant. This is due to the fact that their observed T-values are positive and above the rule of thumb 2 . The other variables are statistically insignificant because of their observed t-values are either negative or far less than the rule of thumb of 2 . From R-squared of 0.859172 , the regression co-efficient indicates that about $83 \%$ of the changes in the dependent variable are explained by the changes in the independent variables. This is due to the fact that the calculated F-value is more than the critical K-value. The D.W. statistics of 2.I49650 indicates the absence of auto-correlation since it is up to rule of Thumb of 2.

\subsection{Testing of Hypothesis}

The following hypotheses have been formulated in null form.

- HOI: Environmental and social costs have no significant effect on Return on Capital employed of manufacturing companies.

- $\mathrm{HO}_{2}$ : Environmental and social costs have no significant effect on the Net Profit Margin of manufacturing companies.

- $\mathrm{HO}_{3}$ : Environmental and social costs have no significant effect on the Dividend Per Share of manufacturing companies.

- $\mathrm{HO}_{4}$ : Environmental and social costs have no significant effect on the Earnings Per Share of manufacturing companies.

To test for the above hypothesis, the researcher had to consider the test of significance, which is the F-statistic. The tool of F-statistic helps in determining the overall joint significant of the explanatory (independent) variables on the dependent or explained variable. At 5\% level of significance, $\mathrm{K}$ critical or $\mathrm{F}$ tabulated is $0.00 \mathrm{I}$ when comparing this with the calculated value from the above table, which are 12.958I5. The decision rule is that, if the calculated value is greater than the tabulated, reject null hypothesis (Ho). Hence, the null hypotheses are rejected since f-cal (I2.958I5) is greater than the f-tab (0.00I). It indicates that the explanatory variables are jointly significant at explaining or causing much variation in the dependent variables is jointly significant at explaining or causing much variation in the dependent variable (Environmental and Social cost). The null hypothesis is therefore rejected, which mean that Environmental and Social Cost has significant relationship with the various variables used in measuring firm profitability. It is also necessary to note that this relationship with the variables of corporate performance is either positive or negative.

\section{Discussions of Findings}

The study revealed the following findings:

- Environmental and social costs has a positive relationship with the Net Profit Margin (NPM) and Dividend Per Share (DPS)

- Environmental and social costs has a negative relationship with the return on capital employed (ROCE) and Earning per Share (EPS).

These findings are in line with studies conducted by Bewley and Li (2000); Hughes, (200I), Al-Tuwariji (2004); Uwaigbe, (2012).

\section{Conclusion}

Environmental and Social costs cover all cost; incurred concerning environmental degradation and depletion of natural resources. It involves management of environmental costs effectively presenting and disclosing environmental information in a suitable form. Different firms may consider different elements into environmental costs but it is important that all significant and relevant costs are incorporated for sound decision making purpose. The general picture, which emerges from current reporting, is that since the disclosures of environmental information are voluntary there is a diversity of reporting practice. 
Large companies tend to report more environment information in their annual reports than the medium-scale businesses; and the disclosure, tend to be more qualitative than quantitative despite the fact that there is a significant relationship between environmental accounting and firm profitability.

\section{Recommendation}

Based on the findings of this study the following recommendations are made:

- Government should make Environmental Reporting in annual reports compulsory since most organization hardly report their environmental activities in their report;

- Government agencies should give tax credit to organizations that comply with its environmental laws of the land which will encourage environmental reporting.

- Corporate organizations on their part should ensure that they comply with the environmental laws of the nation as it will go a long way in enhancing their performance.

\section{References}

Adediran, S.A., \& Alade S.O. (2013). Impact of Environmental Accounting on Corporate Performance in Nigeria. European Journal of Business \& Management, 5(23). London.

Akpan, F.E. (2013). Principles of Environmental Accounting in Oil and Gas Industry. Larigraphics Ltd, Jos, Nigeria.

Daniel, L.N. (2013). The effect of environmental regulation on financial performance in Tanziania: A survey of manufacturing companies quoted on the Dar Es Salam stock exchange. International Journal of Economics and Financial Issues, $3(\mathrm{I}), 99-\mathrm{II} 2$.

Deegan, C. (2002). Legitimacy effect of Social and Environmental Disclosures a Theoretical Foundation. Accounting, Auditing and Accountability.

Deegan, C \& Gordon, B.(I962). A study of the Environmental Disclosure Practices of Australian Corporations. Accounting and Business Research Journal.

EPA. (1996). Valuing Potential Environmental Liabilities for Managerial Decision- Making: A Review of Available Techniques, United States Environmental Protection Agency, Office of pollution Prevention and Toxics, Washington.

Freeman, A.B. (1983). Towards an Epistemology for Radical Accounting: Beyond Objectivism and Relativism. Critical Perspective on Accounting.

Gotherstron, Y. (2012). Environmental Accounting; Theoretical Review; Masters in Accounting Thesis, University of Gotoborg's Sweden.

Growther, D. (2000). Social and Environmental Accounting (p.20). London, Finance Times Prentice Hall.

Iheduru, N.G. (2018). Unpublished Lecture Notes on Social and Environmental Accounting, Imo State University, Owerri.

Islam, M.A and Deegan, E.C. (2008). Motivation for organizations within a Developing country \& Report Social Responsibility Information: Economics and information Technology Issue.

KPMG, United Nations Environment Programme (UNEP). (2006). Carrots and sticks for Starters' Current Trends and Approaches in voluntary and Mandatory Standards for Sustainability Reporting, Parktown: KPMG.

Labaran S.A. (20I I). Petroleum Resource and Environmental Accounting Oil and Gas. Lecaps Publishers, Jos, Nigeria.

Letmathe P, Doost R K. (2000). Environmental Cost Accounting and Auditing Management and Audit Journal.

Nigerian Stock Exchange. (2014). Annual Financial Report of Quoted Manufacturing Companies. Retrieved from http://www.topforeignstock.com/stock-list-of-listed-companies-in-nigeria.html

Odetayo, T.A., Adeyemi, A.Z., \& Sajuyigbe, A. S. (20I4). Impact of Corporate Social responsibility on profitability of Nigeria banks. International Journal of Academic Research in Business and Social Sciences, 4(8), 252-263. http://dx.doi.org/I0.600//ijarbss/v4-I8/1094

Palmer, H.J. (2012). Corporate Social responsibility and financial performance: Does it pay to be good? CMC Senior Thesis, USA Claremont College.

Schaltegger, S. \& Burritt, R. (2000). Contemporary Environment Accounting, Sheffiled, UK: Greenleaf Publishing.

Schman M.C. (1995). Managing Legitimacy Strategic and Institutional approaches. Academy and of Management Review.

Tillimg. (2008). Determination of Corporate Social Responsibility Disclosure; An Application of Stakeholders and Legitimacy Theory. Accounting Organizations and Society.

Uwaigbe, U.,\& Jimoh, L. (2012). Corporate Environmental Disclosure in Nigerian Manufacturing Industry. Multidisciplinary Journal Ethiopia. 6(3), 73

Wason. V. (2005). Double Entry Book keeping (financial accounting S.Chand and Company Ltd, Ram Nagar, New Delhi.

Watts, R.L., \& Zimmerman, J.L. (I978). Towards a positive Theory of the determination of Accounting Standards, Accounting Review, 54(2), I I2-I34. 


\section{Appendix I}

\begin{tabular}{|c|c|c|c|c|c|}
\hline Name of Company & $\begin{array}{l}\text { ESC } \\
\mathrm{N}\end{array}$ & ROCE \% & NPM \% & DPS N & EPS N \\
\hline Nigeria Breweries plc & $20,600.000$ & 67 & 17 & 65 & $50 \mathrm{I}$ \\
\hline Flour Mills of Nigeria & $19,400,000$ & 19 & 5.5 & 60 & 388 \\
\hline Nestle Nigeria & $14,000,000$ & 75.5 & 9.9 & 55 & 2.12 \\
\hline P Z Cussons & II $, 400,000$ & 86.6 & 3.5 & 45 & 80 \\
\hline Dufil Prima Foods & $17,800,000$ & 42.8 & 5.8 & 50 & 649 \\
\hline Lafarge Cement & $52,900,000$ & 34.5 & 15.5 & 70 & 926 \\
\hline British American Tobacco & $58,500,000$ & 8.7 & 27.6 & 45 & II.I \\
\hline Nexans Nigeria & $7,600,000$ & 52.5 & 6.5 & 30 & 35 \\
\hline Cadbury Nigeria plc & $4,000,000$ & 33.9 & 5.4 & 25 & 27 \\
\hline Unilever Nigeria plc & 800,000 & 18.6 & 13.8 & 25 & 25 \\
\hline Dangote sugar plc & $\mathrm{I}, 700,000$ & 37.6 & 1.6 & 20 & 5 \\
\hline Berger ple & $4,000,000$ & 44.4 & 15.8 & 40 & 78 \\
\hline Emzor pharmaceutical ple & $5,000,000$ & 39.3 & 1.5 & 35 & 2 \\
\hline Coca-Cola Bottling Company & $31,600,000$ & 31.2 & 27 & 55 & 315 \\
\hline
\end{tabular}

Source: 2016 Nigerian Stock Exchange Annual Financial Report

\section{Appendix II}

\begin{tabular}{lrrrr}
\hline \multicolumn{1}{c}{ Variable } & Coefficient & Std Error & \multicolumn{1}{c}{ T-Statistic } & \multicolumn{1}{c}{ Prob } \\
\hline ESC & 8939618 & 7253516 & $-\mathrm{I} 248435$ & 0.3562 \\
\hline ROCE & -29863504 & $\mathrm{I} 3093548$ & -3.579789 & 0.0250 \\
\hline NPM & 85688928 & 45425547 & 2.633716 & 0.410 \\
\hline DPS & 73438732 & $\mathrm{I} 4624 \mathrm{I} 2$ & 4.802550 & $0.002 \mathrm{I}$ \\
\hline EPS & -806577.6 & 387849.9 & -1.964308 & 0.0872 \\
\hline R-Squared & 0.859172 & Mean dependent Var & & 16958142 \\
\hline Adjusted R-squared & 0.777678 & S.D dependent Var & \\
\hline S.E of regression & 8245645 & Akaike info criterion & 3585459 \\
\hline Sum squared & $5.98 \mathrm{E}+\mathrm{I} 2$ & Schewarz criterion & 37.17405 \\
\hline Log likelihood & -249.4506 & F-statistic & $\mathrm{I}$ \\
\hline Durbin-Watson stat & 2.149650 & Prob (F-statistic) & 0.001375 \\
\hline
\end{tabular}

\section{Copyrights}

Copyright for this article is retained by the author(s), with first publication rights granted to the journal. This is an open-access article distributed under the terms and conditions of the Creative Commons Attribution license (http://creativecommons.org/licenses/by/4.0/). 